\title{
Image Credits
}

Figure 9.2 "Landscape with the Fall of Icarus" (c.1558) by Pieter Brueghel the Elder (1526/1530-1569) from the Musées Royaux des Beaux Arts, Brussels, Belgium / Public domain 180

Figure 9.3 Photo of Buddha sculpture at the house of the 'Resident' in Kediri, Indonesia, from the Tropenmuseum, part of the National Museum of World Cultures / CC BY-SA (https://creativecommons.org/ licenses/by-sa/3.0) 183

Figure 9.4 Coloured print of a Highlander and a black slave, smoking a pipe and taking snuff, possibly an advertisement for tobacco, c. 1790. (C) National Museums Scotland. Licensor: www.scran.ac.uk. 185

Figure 9.5 Poster for Armenian and Syrian Relief Campaign c. 1918. National Archives at College Park, Maryland, USA / Public domain 187

Figure 9.6 Madonna and Child by Giovanni Bellini from the Bernasconi Collection, Castelvecchio Museum, Verona, Italy / CC BY-SA (https:// creativecommons.org/licenses/by-sa/3.0) 188

Figures $9.7 \& 9.8$ Brazilian political campaign posters; photographs taken by the author 189

Figure 9.9 Photograph of Gendou Missile / CC BY-SA (https://creativecommons.org/licenses/by-sa/3.0) 194

Figure 9.10 Photograph of billboards in Causeway Bay, Yee Wo Street and Paterson Street, July 2020, by Lynuetyeang UV2002 / CC BY-SA 4.0 (https://creativecommons.org/licenses/by-sa/4.0) 200

Figure 9.11 Billboard advertisement in São Paulo for Casa do Pão de Queijo, photograph taken by the author. 201

Figure 10.2 Screenshot of frequencies of occurrence of 'one nation conservatism' in NOW from 2010-early 2020; from Davies, Mark. (2016-) 
xiv Image Credits

Corpus of News on the Web (NOW). Available online at https://www .english-corpora.org/now/ 215

Figure 10.3 Screenshot of Jô Soares interviewing Patrick Swayze on Jô Soares onze e meia (SBT, 1995) https://www.youtube.com/watch?v =i8GeH5oXIw8 (4’34”) 229 